\title{
Pelatihan Pengolahan Pakan Asal Limbah Pertanian di Desa Moyo Mekar Moyo Hilir Sumbawa
}

\author{
Muhamad Amin, SD Hasan, Oscar Yanuarianto, Suhubdy, Syamsul Hidayat Dilaga
}

Fakultas Peternakan, Universitas Mataram, Mataram, Indonesia

\section{Article history}

Received: 30-11-2020

Revised: 09-03-2021

Accepted: 07-03-2021

*Corresponding Author:

Muhamad Amin,

Fakultas Peternakan,

Universitas Mataram, Mataram, Indonesia;

Email:

muhamadamin686@yahoo.co.id
Abstract: As an effort to improve the knowledge and skills of rural breeders, community service activities have been carried out with the topic "Training on Feed Processing from Agricultural Waste in Moyo Mekar Village of Moyo Hilir Sumbawa." This service activity was held on the grounds that breeders in Moyo Mekar Village often experience difficulties to meet the needs of their livestock for forage, especially during the dry season, so this sometimes has an unwanted negative impact, such as the occurrence of cases of death and disease in livestock as a result of the declining condition of the livestock. This is due to the ignorance of the breeders in their efforts to overcome the shortage of forage during the dry season. This community service activity has been carried out using three methods, namely lecture, written and demonstration methods. With the lecture method, it was conveyed about the understanding and explanation of how to preserve and treat agricultural waste. Through the written method, it is conveyed by giving brochures to the breeder members. Meanwhile, with the demonstration method, the breeders directly practice ways of preserving and treating agricultural waste. Based on the results of monitoring during the activity, the results of questions and answers and the enthusiasm of the participants, it was seen that the new breeders realized how important the role of nutrition was for livestock, the availability of applying preservation and feed processing technology, and it could also be seen that they had no difficulty in adopting the material provided, then Overall this activity can be said to be quite successful. Recognizing the limitations of the breeders in terms of preservation and processing of feed which is an alternative for providing feed in the dry season, it is suggested that this kind of activity should be continued so that the expected livestock production can be achieved.

Keywords: counseling; demonstration; rice straw; ammonition; Moyo Mekar

Abtrak: Sebagai upaya untuk meningkatkan pengetahuan dan keterampilan para peternak di pedesaan maka telah dilaksanakan kegiatan pengabdian dengan topik "Pelatihan Pengolahan Pakan Asal Limbah Pertanian di Desa Moyo Mekar Moyo Hilir Sumbawa" Kegiatan pengabdian ini diadakan dengan alasan bahwa para peternak di Desa Moyo Mekar ini sering mengalami kesulitan untuk memenuhi kebutuhan ternaknya akan pakan hijauan terutama pada waktu musim kemarau berlangsung, sehingga hal ini kadang-kadang memberikan dampak negatif yang sebenarnya tidak dikehendaki seperti terjadinya kasus kematian dan timbul penyakit pada ternak sebagai akibat kondisi ternak yang menurun. Hal ini disebabkan karena ketidaktahuan para peternak dalam upaya untuk mengatasi kekurangan pakan hijauan pada saat musim kemarau tersebut. Kegiatan pengabdian kepada masyarakat ini telah dilaksanakan dengan tiga metode, yaitu metode ceramah, tertulis dan demonstrasi. Dengan metode ceramah disampaikan mengenai pengertian dan penjelasan tentang cara pengawetan dan pengolahan 
limbah pertanian. Melalui metode tertulis disampaikan dengan memberikan brosur kepada anggota peternak. Sedangkan dengan metode demonstrasi, para peternak langsung memperaktekan cara pengawetan dan pengolahan limbah pertanian. Berdasarkan hasil pemantauan selama kegiatan, hasil tanya jawab dan antusias para peserta, terlihat para peternak baru menyadari betapa pentingnya peranan nutrisi bagi ternak, ketersediaan menerapkan teknologi pengawetan dan pengolahan pakan, dan dapat dilihat pula bahwa mereka tidak mengalami kesulitan dalam mengadopsi materi yang diberikan, maka secara keseluruhan kegiatan ini dapat dikatakan cukup berhasil. Menyadari adanya keterbatasan para peternak dalam hal pengawetan dan pengolahan pakan yang merupakan alternatif penyediaan pakan di musim kemarau, maka disarankan agar kegiatan semacam ini hendaknya dapat dilanjutkan sehingga produksi ternak yang diharapkan dapat tercapai.

Kata Kunci: penyuluhan; demonstrasi; jerami padi; amoniasi; Moyo Mekar

\section{PENDAHULUAN}

Desa Moyo Mekar merupakan salah satu Desa yang ada di Kecamatan Moyo Hilir, Kabupaten Sumbawa, Provinsi Nusa Tenggara Barat. Desa ini terdiri dari daerah persawahan, tegalan, perkebunan dan hutan. Penduduknya bermatapencaharian sebagai petani tanaman pangan dan sekaligus sebagai peternak. Para peternaknya pada musim kemarau sulit untuk menyediakan kebutuhan pakan ternaknya terutama hijauan yang sebagian besar bersumber dari rumput-rumputan. Hal ini disebabkan karena pada musim kemarau produksi pakan hijauan sangat menurun, selain itu di Desa Moyo Mekar ini penanaman pakan hijauan secara khusus belum dilaksanakan, sebagian besar lahan hanya digunakan untuk penanaman tanaman pangan. Keadaan ini apabila dibiarkan secara terus menerus berkepanjangan tanpa ada upaya untuk menanggulanginya, maka mengakibatkan produktivitas ternak akan menurun.

Hijauan Makanan Ternak merupakan bahan pakan utama bagi kehidupan ternak serta merupakan dasar dalam usaha pengembangan peternakan terutama untuk ternak ruminansia seperti sapi, kerbau, kambing dan domba. Untuk meningkatkan produktivitas ternak, salah satu faktor penting yang harus diperhatikan adalah penyediaan pakan hijauan sepanjang tahun baik kualitas dan kuantitas yang cukup agar pemenuhan kebutuhan zat-zat makanan ternak untuk mempertahankan kelestarian hidup dan keutuhan alat tubuh ternak (kebutuhan hidup pokok) dan tujuan produksi (kebutuhan produksi) dapat berkesinambungan.

Kendala utama di dalam penyediaan hijauan makanan ternak yakni produksinya yang tidak tetap sepanjang tahun. Pada saat musim penghujan, produksi hijauan makanan ternak akan melimpah, sebaliknya pada saat musim kemarau tingkat produksinya akan rendah, atau bahkan dapat berkurang sama sekali. Oleh karena itu dalam mensiasati ketersediaan hijauan makanan ternak yang tidak tetap sepanjang tahun, perlu dilakukan pengolahan atau pengawetan agar supaya pakan hijauan selalu tersedia untuk memenuhi kebutuhan ternak tersebut. Pengolahan pakan merupakan suatu kegiatan untuk mengubah pakan tunggal atau campuran menjadi bahan pakan baru atau pakan olahan. Bahan pakan baru yang dihasilkan dari proses pengolahan diharapkan dapat meningkatkan kualitas, memudahkan penyimpanan dan meningkatkan efisiensi pakan. Pengawetan dan pengolahan pakan dilakukan untuk optimalisasi pemanfaatan potensi pakan lokal dan limbah pertanian/limbah perkebunan serta menjamin ketersediaan pakan secara berkesinambungan. 
Pengawetan dan pengolahan bahan pakan dapat dilakukan dengan cara fisik, kimiawi, biologis dan kombinasinya. Perlakuan secara fisik dapat dilakukan dengan cara penjemuran, pencacah atau pemotongan, penggilingan, penghancuran serta pembuatan pelet. Perlakuan secara kimiawi dilakukan dengan cara menambahkan bahan kimia seperti urea. Amoniasi merupakan salah satu perlakuan bahan pakan secara kimiawi yang bersifat alkalis sehingga dapat melarutkan hemiselulosa dan memutuskan ikatan antara lignin dan selulosa atau hemiselulosa. Perlakuan secara biologis dapat dilakukan dengan cara fermentasi dengan menggunakan mikroba starter, proses fermentasi ini bermanfaat untuk menurunkan kadar serat kasar, meningkatkan kecernaan dan kadar protein bahan pakan (Prastyawan et al., 2012). Perlakuan secara kombinasi dapat dilakukan dengan cara gabungan dari fisik-kimia, fisikbiologi dan atau biologi-kimia. Menurut hasil penelitian Amin, dkk. (2008) bahwa penambahan urea dan starbio pada jerami padi dapat meningkatkan kandungan protein kasar, kecernaan in vitro bahan kering dan bahan organik; menurunkan kadar serat kasar, NDF, ADF, selulosa dan lignin. Amoniasi dan fermentasi jerami padi merupakan suatu metode pengolahan jerami padi yang dapat memecah ikatan selulosa, hemiselulosa dan lignin sehingga jerami padi mudah untuk dicerna (Masnun dan Muda, 2014).

Teknik pengawetan dan pengolahan pakan yang dikombinasikan dengan teknik penyimpanan dan penyajian pakan mampu menjamin kontinuitas ketersediaan pakan sehingga memberi peluang bagi peternak untuk berusaha dalam skala yang lebih besar dan bisa meningkatkan efisiensi usaha peternakan (Adrial dan Mokhtar, 2013).

Berdasarkan pada analisis situasi yang ada di Desa Moyo Mekar tersebut maka dapat dirumuskan permasalahannya sebagai berikut: ketersediaan pakan pada musim kemarau yang tidak memenuhi persyaratan kualitas, kuantitas dan kontinuitas; keterbatasan pengetahuan dan keterampilan para peternak dalam hal pengawetan dan pengolahan pakan; dan peternak belum begitu banyak mengenal teknik pengolahan limbah pertanian. Melihat keadaan di atas, maka permasalahan yang perlu dipecahkan adalah bagaimana meningkatkan pengetahuan dan keterampilan para peternak dalam hal pengawetan dan pengolahan pakan. Untuk itu perlu dilakukan suatu kegiatan yang bertujuan untuk mempercepat dan meningkatkan adopsi teknologi pengawetan dan pengolahan pakan (hay, silase, amoniasi dan fermentasi) dalam bentuk penyuluhan dan pelatihan sebagai upaya peningkatan optimalisasi pemanfaatan rumput-rumputan dan limbah pertanian yang berlimpah pada musim penghujan sebagai pakan ternak.

Setelah kegiatan penyuluhan dan pelatihan diharapkan anggota kelompk peternak mitra dapat meningkat pengetahuan dan keterampilannya dalam hal pengawetan dan pengolahan pakan. Setelah kegiatan pengabdian selesai diperoleh bahan pakan awetan dan olahan. Di samping itu, setelah penyuluhan ini berakhir, para peternak dapat melakukan sendiri kegiatan pengawetan dan pengolahan pakan dengan baik dan lancar.

\section{METODE}

Kegiatan pengabdian kepada masyarakat dilaksanakan dalam dua tahap, yaitu tahap persiapan dan tahap pelaksanaan.

\section{Tahap Persiapan.}

Melalui tahap persiapan ini dilakukan penjajakan terhadap kemungkinan dilaksanakan kegiatan pengabdian bagi anggota kelompok peternak mitra dengan memperhatikan berbagai potensi yang 
mendukung untuk terlaksananya program pengabdian, seperti populasi ternak, adanya kelompok kandang kolektif dan kondisi para peternak mitra khususnya mengenai tingkat pengetahuan dan keterampilan dalam hal pengawetan dan pengolahan limbah pertanian dan memperhatikan hal-hal yang berhubungan dengan motivasi anggota kelompok peternak mitra untuk mengembangkan usahanya.

Semua data yang berhubungan dengan hal-hal di atas dapat diperoleh melalui pendekatan langsung dengan Kepala Desa, Kepala Kampung dan anggota kelompok peternak mitra. Dalam kegiatan penjajakan ini ditentukan waktu dan tempat kegiatan dilangsungkan.

\section{Tahap Pelaksanaan.}

Pelaksanan program pengabdian di Kelompok peternak mitra ini dilakukan dengan tiga metode, yaitu metode ceramah, tertulis dan demonstrasi. Dengan metode ceramah disampaikan dengan memberikan pengertian dan penjelasan kepada para peternak mengenai cara pengolahan limbah pertanian (Amoniasi Jerami padi). Melalui metode tertulis disampaikan dengan memberikan diktat praktis yang berisi cara pengolahan jerami padi dengan urea. Sedangkan dengan metode demonstrasi dan pelatihan yaitu melakukan praktek langsung tentang pengolahan jerami padi dengan urea oleh anggota kelompok peternak mitra itu sendiri.

Dalam melaksanakan kegiatan pengabdian kepada masyarakat ini, selain penyampaian materi utama (pengolahan jerami padi dengan teknologi Amoniasi), disampaikan juga materi tambahan yang berkaitan dengan pengawetan dan pengolahan pakan, yaitu pengolahan jerami padi dengan teknologi Amofer, pengawetan hijauan dengan teknologi silase dan pengawetan hijauan dengan pembuatan hay.

\section{HASIL DAN PEMBAHASAN}

\section{Hasil Kegiatan Pengabdian Kepada Masyarakat}

Hasil kegiatan pengabdian kepada masyarakat ini dapat dilihat terutama terhadap tingginya respon para peternak pada saat mengikuti pertemuan-pertemuan (Gambar 1). Hal ini ditandai oleh adanya antusias mereka dalam mengikuti baik ceramah maupun pada waktu berlangsungnya praktek. Tendensi lain untuk mengukur keberhasilan kegiatan ini adalah munculnya berbagai pertanyaan yang berkaitan dengan cara pengawetan dan pengolahan jerami padi. Animo para peserta untuk melaksanakan demonstrasi secara langsung cukup tinggi.

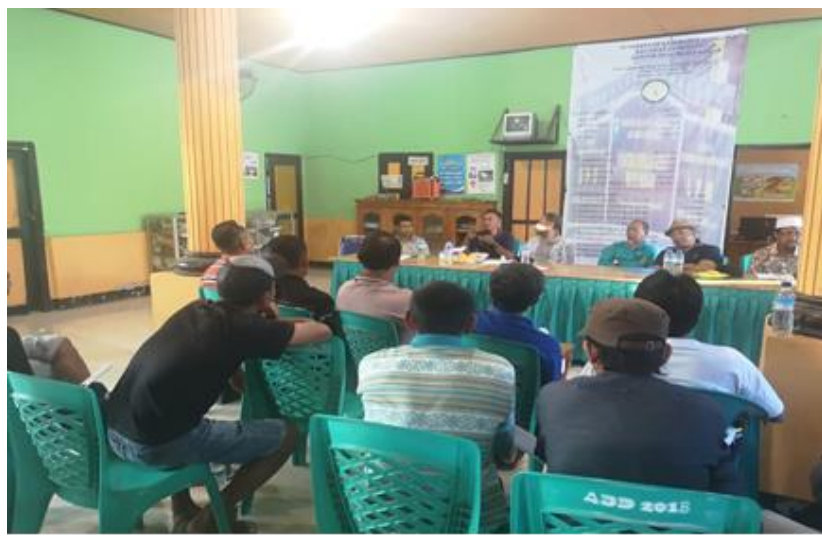

Gambar 1. Suasana pertemuan saat penyampaian materi dan diskusi

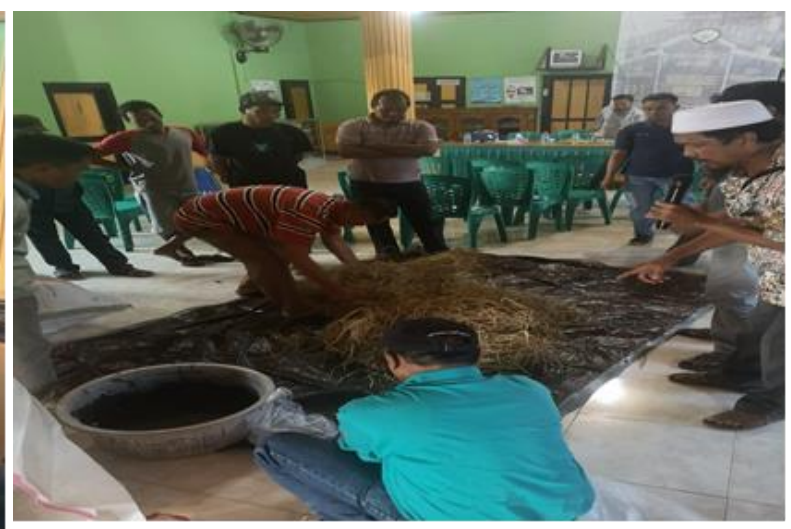

Gambar 2. Demonstrasi pembuatan jerami padi amoniasi 
Hasil pengamatan selama berlangsungnya kegiatan baik pada saat ceramah maupun pengamatan selama berlangsungnya acara demonstrasi, terlihat bahwa para peserta kegiatan dapat menguasai apa yang disampaikan dengan mudah. Hal ini ditandai oleh terjadinya komunikasi dua arah yang di ekspresikan oleh adanya berbagai saran, pertanyaan dan usul yang diajukan oleh para petani peternak.

Dalam melaksanakan demonstrasi pembuatan jerami padi amoniasi (Gambar 2), para peternak tidak mengalami kesulitan disebabkan bahan-bahan/alat-alat yang diperlukan sudah dikenal dan mudah memperolehnya. Keinginan untuk meningkatkan keterampilannya ternyata sangat tinggi, hal ini dapat dilihat dengan adanya aktifitas yang diperlihatkan selama praktek atau demonstrasi, yaitu mulai saat praktek sampai dengan pembukaan hasil olahan jerami padi. Para petani peternak Desa Moyo Mekar memperlihatkan minat yang cukup tinggi terhadap inovasi baru, hal ini disebakan karena semangat yang tinggi unutk mengembangkan usahanya.

\section{Analisis Hasil Pengabdian Kepada Masyaraka}

Analisis hasil terhadap pengabdian kepada masyarakat berupa pengolahan jerami padi dengan urea bagi peternak di Desa Moyo Mekar dilakukan terhadap tiga faktor, yaitu:

\section{Faktor Penghambat}

Secara umum pelaksanaan pengabdian kepada masyarakat di Desa Moyo Mekar ini dapat berjalan dengan lancar sesuai dengan rencana yang ditetapkan, akan tetapi kegiatan rutin para peserta yang cukup banyak menyebabkan terbatasnya waktu dilaksanakan kegiatan pengabdian ini, namun demikian seluruh rangkaian kegiatan dapat diselesaikan dengan hasil yang cukup memuaskan.

\section{Faktor Pendukung}

Faktor Pendukung pelaksanaan kegiatan ini sebagai berikut:

a. Adanya dukungan positif dari para pemuka masyarakat Desa, Kepala Desa dan Aparatnya.

b. Para petani peternak sering mengalami kesulitan untuk memenuhi pakan ternaknya terutama pada saat berlangsungnya musim kemarau.

c. Jerami padi pada saat panen cukup banyak tersedia, sehingga tidak mengalami kesulitan dalam mengumpulkannya.

d. Pupuk Urea yang digunakan dalam pengolahan ini sudah lama mereka kenal, dengan mudah dapat diperoleh. Dengan adanya faktor-faktor di atas, maka dapat mendorong kelancaran pelaksanaan kegiatan pengabdian ini.

\section{Evaluasi}

Pelaksanaan kegiatan pengabdian ini dilakukan di Desa Moyo Mekar Kecamatan Moyo Hilir Sumbawa dengan sasaran utama Kelompok Tani Ternak Desa Moyo Mekar. Bila diamati lokasi pelaksanaan kegiatan ini adalah merupakan daerah pertanian yang cukup potensial untuk dikembangkan, karena di samping pertanian tanaman pangan, sektor peternakan cukup baik untuk mendapat perhatian mengingat sebagian masyarakatnya mempunyai kegiatan usaha di bidang peternakan tersebut.

Permasalahan yang sering mereka hadapi adalah sering megalami kesulitan pakan ternak pada musim kemarau, untuk mengatasi persoalan ini pemanfaatan teknologi pengolahan jerami padi adalah 
merupakan salah satu alternatif yang paling tepat sehingga dapat dikatakan bahwa pelaksanaan pelayanan dengan materi tersebut adalah sangat relevan dengan kondisi masyarakat setempat. Hal ini memberikan prospek ke arah pengembangan peternakan sapi di Desa Moyo Mekar ini secara lebih intensif.

Berdasarkan hasil evaluasi Tim pengabdian selama berlangsungnya kegiatan pengabdian maka pembinaan yang terus menerus secara lebih insentif masih diperlukan agar teknologi yang telah diperoleh akan dapat membudaya dalam upaya mengatasi permasalahan yang dihadapi terutama pada musim kemarau dimana pakan ternak sulit diperoleh.

Dilihat dari prosedur, maka teknik pengolahan jerami padi ini cukup baik dan bermanfaat bagi petani peternak, karena di samping kondisi alam setempat yang mendukung juga bahan-bahan yang diperlukan cukup mudah dan harganya murah. Oleh karena itu sangat diharapkan agar teknologi pengolahan jerami padi dengan urea ini dapat dipraktekkan dengan baik oleh peternak sehingga dapat memberi andil dalam mengembangkan usahanya sekaligus diharapkan akan meningkatkan pendapatan yang pada gilirannya akan dapat meningkatkan taraf hidup dan kesejahteraan mereka.

\section{Jerami Padi Sebagai Pakan Ternak}

Jerami padi adalah sisa dari tanaman padi setelah biji dan butiran dipetik untuk kepentingan manusia dan telah dipisahkan dari akarnya (Lubis, 1963). Jerami padi terdapat dalam jumlah yang melimpah dan mudah diperoleh untuk dimanfaatkan sebagai pakan. Ketersediaan jerami padi selalu meningkat seiring dengan meningkatnya produksi padi. Jackson (1977) menyatakan bahwa jerami padi mengandung $80 \%$ bahan yang secara potensial dapat dicerna dan merupakan sumber energi yang besar bagi ternak ruminansia. Pada musim kemarau persediaan hijauan segar kurang, pemanfaatan jerami padi menjadi sangat besar, hal ini menuntut adanya peningkatan kualitas nutrisi jerami padi tersebut, sehingga potensi yang dimiliki jerami padi muncul sebagai realita dalam mendukung persediaan pakan.

Walaupun jerami padi mempunyai kandungan protein kasar yang rendah, namun dari beberapa hasil penelitian yang telah dilakukan membuktikan bahwa jerami padi mempunyai prospek yang cukup cerah sebagai pakan ruminansia terutama sebagai sumber energi (Saadullah, 1981). Secara umum dikatakan bahwa nilai nutrisi jerami padi rendah. Karena jerami padi merupakan produk pakan tua sehingga proses lignifikasi telah berlanjut. Selulosa dan hemiselulosa sebagian terdapat sebagai senyawa komplek lignoselulosa dan lignohemiselulosa; sebagian dari selulosa berubah bentuk, dari bentuk amorf menjadi kristal. Molekul-molekul dalam kristal terletak sangat berdekatan karena banyak kristal silika yang mengisi ruang antar sel maka enzim pencernaan sukar menembusnya. Di samping itu kandungan protein kasar jerami padi sangat rendah (Djajanegara,1983). Rendahnya kualitas jerami padi disebabkan oleh rendahnya kandungan protein kasar (3-4\%), daya cerna (36-40\%) dan tingginya kandungan silika, lignoselulosa dan lignohemiselulosa.

Hasil analisa kimia jerami padi menunjukkan keragaman komposisi kimianya, dipengaruhi oleh varietas dan tempat tumbuhnya, tetapi secara umum terlihat jelas bahwa kandungan protein kasar jerami padi rendah, sedangkan serat kasarnya tinggi dan memiliki nilai kecernaan yang rendah (Komar,1984).

Mengingat potensi jerami padi yang cukup besar untuk mendukung penyediaan pakan ternak ruminansia, maka usaha yang ditunjukkan untuk meningkatkan kandungan zat makanan dan daya cerna memegang peranan penting dalam upaya menigkatkan nilai guna jerami padi. Menurut Komar (1984), peningkatan daya cerna jerami padi dapat dilakuakan dengan usaha pemutusan ikatan 
hidrogen antara lignin dengan selulosa dan hemiselulosa, antara lain dengan cara amoniasi. Perlakuan amoniak (NH3) selain meningkatkan kecernaan dinding sel dan kandungan protein kasar juga tidak menimbulkan polusi. Salah satu sumber amoniak yang digunakan dalam proses amoniasi adalah urea.

Amoniak yang berasal dari urea akan terfiksasi di dalam jaringan jerami padi dan akan berikatan dengan gugus asetil untuk selanjutnya akan membentuk garam ammonium. Menurut Komar (1984), nitrogen yang terfiksasi ini ternyata bertahan dalam jaringan tanaman tersebut meskipun dipanaskan. Selanjutnya ditemukan bahwa amoniak yang terfiksasi dalam jaringan tanaman akan berfungsi untuk menghidrolisa ikatan lignoselulosa, menghancurkan ikatan lignohemiselulosa, khusus untuk jerami padi dapat melarutkan sebagian silika. Reaksi yang terjadi menyebabkan mengembangnya jaringan dan meningkatkan fleksibilitas dinding sel sehingga memudahkan penetrasi oleh enzim selulase yang dihasilkan oleh mikroorganisme rumen. Menurut Doyle et. al. (1986), penambahan urea pada jerami padi dapat meningkatkan kandungan protein kasar dan daya cerna jerami padi. Peningkatan daya cerna jerami padi ini diduga karena terjadinya proses amoniasi, dalam kondisi basa selulosa akan mengembang sehingga akan mudah dicerna oleh enzim yang dihasilkan oleh mikroorganisme rumen. Sedangkan peningkatan protein kasar terjadi karena terbentuknya garam ammonium asetat yang mengandung nitrogen yang dapat langsung digunakan oleh mikroorganisme.

AMOFER adalah singkatan dari AMOniasi dan FERmentasi. Dalam AMOFER ini dikenal dua proses. Proses yang pertama adalah Amoniasi yaitu suatu cara pengolahan jerami padi dengan menggunakan urea. Dalam proses amoniasi, amonia berperan untuk menghidrolisis ikatan lignin selulosa, menghancurkan ikatan hemiselulosa dan memuaikan serat selulosa sehingga memudahkan penetrasi enzim selulase dan meningkatkan kadar nitrogen sehingga kandungan protein kasar meningkat. Proses yang kedua adalah fermentasi yaitu suatu proses an-aerob dengan memanfaatkan campuran beberapa bakteri seperti proteolitik, selulotik, lipolitik dan lignolitik. Melalui kombinasi teknologi AMOFER ini dapat meningkatkan nilai gizi dan kecernaan jerami padi yang pada akhinya dapat meningkatkan produktivitas ternak.

Dengan teknologi amoniasi, serat-serat jerami padi menjadi lunak sehingga serat menjadi lebih mudah untuk disusupi mikroba rumen dan kemudian mudah didegradasi. Oleh sebab itu, terjadinya peningkatan kecernaan jerami padi tidak hanya oleh proses fermentasi oleh mikroba tetapi juga disebabkan oleh proses hidrolisis basa lemah (amoniasi). Melalui proses fermentasi jerami padi dengan EM4, urea juga ditambahkan ke dalamnya sehingga selama proses pemeraman juga terjadi proses amoniasi (Akmal et al., 2004). Pada proses fermentasibdengan Probion, penggunaan urea dimaksudkan untuk menjadi sumber amonia yang diperlukan untuk pertumbuhan atau perkembangan mikroba dalam proses fermentasi tersebut (Haryanto et al., 2004). Lama waktu fermentasi dapat meningkatkan kandungan protein kasar dan kecernaan in vitro bahan kering dan bahan organik; menurunkan kadar serat kasar, NDF, ADF, selulosa dan lignin jerami padi amoniasi yang ditambah probiotik Bacillus sp. (Amin, dkk., 2012)

Dalam kegiatan pengabdian ini, sumber amoniak yang dipergunakan adalah urea. Urea dengan rumus molekul $\mathrm{CO}$ (NH2)2 banyak digunakan dalam ransum ternak ruminansia karena mudah diperoleh, harga murah dan sedikit keracunan yang diakibatkannya dibanding biuret (Hanafi, 2004). Penggunaan urea dalam proses amoniasi jerami dibatasi sampai maksimal 6\% (4\%-6\%) dari berat kering jerami (Bata, 2008) sebab bila terlalu berlebihan dapat menyebabkan keracunan pada ternak.

Hijauan pakan ternak yang diamoniasi dalam kegiatan pelatihan ini adalah jerami padi. Jerami padi cukup potensial untuk dijadikan sumber pakan ternak sebab masih memiliki nutrisi yang dibutuhkan ternak sapi dan ketersediaannya berlimpah pada saat musim panen. Hanafi (2004) 
menyatakan bahan kering hijauan kaya akan serat kasar, karena terdiri dari kira-kira $20 \%$ isi sel dan $80 \%$ dinding sel. Dinding sel terutama tersusun dari dua jenis serat yaitu yang larut dalam detergen asam yaitu hemiselulosa dan sedikit protein dinding sel, dan yang tidak larut dalam detergen asam yakni ligno-selulosa, yang lazim disebut Acid Detergen fiber .

Proses Amoniasi jerami padi dengan urea yang dilakukan di Desa Moyo Mekar selama 21 hari adalah dengan cara basah. Selama proses amoniasi, amoniak akan menghidrolisa ikatan ligninselulosa, menghancurkan ikatan hemiselulosa, memuaikan atau mengembangkan serat selulosa sehingga memudahkan penetrasi enzim selulase, serta meningkatkan kadar nitrogen sehingga kandungan protein kasar juga meningkat (Komar, 1984). Cheeke (1999), menyatakan bahwa kandungan serat kasar mengalami penurunan karena teknik amoniasi dengan menggunakan urea sebagai sumber Non-Protein Nitrogen (NPN) dapat menghancurkan ikatan-ikatan lignin, selulosa, hemiselulosa dan silika yang merupakan faktor penyebab rendahnya daya cerna jerami padi bagi ternak. Menurut Bacon et al. (1981) Perlakuan alkali dengan menggunakan urea menyebabkan membengkaknya selulosa, memutuskan ikatan lignin yang melindungi dinding sel polisakarida sehingga enzim mikroba rumen dapat masuk dan mencerna selulosa tersebut.

Berdasarkan hasil pengamatan secara fisik terhadap jerami padi amoniasi yang dibuat setelah 21 hari, terlihat tekstur jerami lebih lembut dibandingkan pada saat sebelum diberi perlakuan dan berwarna kecoklatan. Berdasarkan pedoman yang dikeluarkan oleh DitJenNak (2011) kriteria amoniasi yang baik adalah berwarna kecoklat-coklatan, kering, jerami amoniasi lebih lembut dibandingkan jerami asalnya.

Jerami padi amoniasi yang telah berhasil dibuat sebelum diberikan kepada ternak sapi, sebaiknya diangin-anginkan terlebih dahulu selama kurang lebih seminggu hingga kadar airnya mencapai $20 \%$. Bila tersedia konsentrat, maka sebaiknya konsentrat diberikan terlebih dahulu kirakira satu jam sebelum pemberian jerami, hal ini dimaksudkan untuk merangsang perkembangbiakan mikroorganisme dalam rumen karena karbohidrat siap pakai dan protein yang tersedia dalam konsentrat cukup sebagai pendorong perkembangbiakan mikroorganisme dalam rumen terutama bakteri selulolitik yang mencerna serat kasar jerami padi.

\section{KESIMPULAN DAN SARAN}

\section{Kesimpulan}

Berdasarkan hasil pemantauan selama berlangsungnya kegiatan pengabdian dan antusias para peternak terlihat para peternak menyadari betapa pentingnya arti pengolahan limbah pertanian bagi ternaknya, kesediaan menerapkan teknologi pengolahan jerami padi Amoniasi dan para peternak tidak begitu mengalami kesulitan dalam mengadopsi materi yang diberikan, maka dapat disimpulkan bahwa kegiatan pengabdian kepada masyarakat yang dilakukan di Desa Moyo Mekar Kecamatan Moyo Hilir Kabupaten Sumbawa dapat dikatakan cukup berhasil.

\section{Saran}

Menyadari adanya keterbatasan pengetahuan dan keterampilan para peternak dalam hal Teknologi pengolahan jerami padi yang merupakan salah satu alternatif penyediaan pakan pada musim kemarau, maka disarankan agar kegiatan semacam ini hendaknya dapat diteruskan sehingga produksi ternak yang diinginkan dapat tercapai. 


\section{DAFTAR PUSTAKA}

Adrial dan Saleh Mokhtar, 2013. Penerapan Teknologi Pengolahan dan Pengawetan Hijauan Pakan di Lokasi Model Pengembangan Pertanian Pedesaan Melalui Inovasi (M-P3MI) di Desa Kanamit Barat Kabupaten Pulang Pisau. Buletin Inovasi Teknologi Pertanian. LITKAJIBANGRAP. 1(1). 27-33.

Akmal, J., Andayani dan Novianti., 2004. Evaluasi Perubahan Kandungan NDF, ADF dan Hemiselulosa pada Jerami Padi yang Difermentasi dengan Menggunakan EM4. Jurnal Ilmiah Ilmu-Ilmu Peternakan. 7(3): 168:173.

Amin, M., M. Iqbal dan Mastur., 2008. Penggunaan Urea dan Probiotik Starbio untuk Peningkatan Kualitas Jerami Padi. Laporan Penelitian. Fakultas Peternakan Universitas Mataram, Mataram.

Amin, M., Sofyan, D.H., Oscar,Y. dan M.Iqbal., 2012. Pengaruh Lama Fermentasi terhadap Peningkatan Kualitas Jerami Padi Amoniasi yang Ditambah Probiotik Bacillus sp. Laporan Penelitian. Fakultas Peternakan Universitas Mataram, Mataram.

Bacon, J.S.D.A., Chesson and A.H.Gordon. 1981. Deacetylation and enhancement of digestibility. Afric. Environm. 6: 124-125.

Bata, M. 2008. Pengaruh Molases Pada Amoniasi Jerami Padi Menggunakan Urea Terhadap Kecernaan Bahan Kering dan Bahan Organik In Vitro. Agripet: Vol (8) No. 2: 15-20

Cheeke., Peter, R., 1999. Applied Animal Nutrition; Feed and Feeding. Third Edition.

Prentice-Hall, Inc: New Jersey

Direktorat Jenderal Peternakan dan Kesehatan Hewan. 2011. Pedoman Umum Pengembangan Lumbung Pakan Ternak. ditjennak.pertanian.go.id/download.php?. Download Tanggal 27 Oktober 2015.

Djajanegara, A., 1983.NTinjauan Ulang mengenai Evaluasi Suplemen pada Jerami Padi. Seminar Pemanfaatan Limbah Pasangan dan Limbah Pertanian untuk Makanan Ternak. Yogyakarta, 10-12 Januari 1983.

Doyle, PT. C., Davendra and G.R Pearce., 1986. Rice Straw as a feed for Ruminant The Australian Development Assistrance Bureau, Canberra.

Hanafi, N.D. Perlakuan Silase Dan Amoniasi Daun Kelapa Sawit Sebagai Bahan Baku Pakan Domba. http://repository.usu.ac.id/bitstream/123456789/815/1/ternak-Nevy.pdf. Download 26 Oktober 2015

Haryanto, B., C.A.V. Lema, Yulianti, Surayah dan Abdurachman., 2004. Peningkatan Degradasi Serat Jerami Padi Melalui Proses Fermentasi dan Suplementasi Zink-Methionin. Proseding Seminar Nasional Teknologi Peternakan dan Veteriner, Bogor 4 - 5 Agustus 2004. Puslitbang Peternakan, Bogor. Hal. 805 - 812.

Komar, A., 1984. Teknologi Pengolahan Jerami Padi sebagai Makanan Ternak. Penerbit Yayasan Grahita. Indonesia.

Lubis, D.A., 1963. Ilmu Makanan Ternak. Cetakan ke II. PT. Pembangunan.Jakarta.

Masnun dan Widyaiswara Muda, 2014. Teknologi Jerami Fermentasi Sebagai Pakan Ternak.www.bppjambi.info/dwn publikasi.asp.id. Diakses Tanggal 06 April 2015. 
Prasetyawan, R.M., B.I.M. Tampoebolon dan Surono, 2012. Peningkatan Kualitas Tongkol Jagung Melalui Teknologi Amoniasi Fermentasi (AMOFER) Terhadap Kecernaan Bahan Kering, Bahan Organik dan Protein Total Secara in-Vitro. J. Animal Agriculture.Vol.1 No.1, 2012. Pp. 611-621.

Saadullah, 1981. Practical Methods for Chemical Treatment of Rice Straw for Ruminant Feeding in Bangladesh. In Utilization of Low Quality Roughages in Africa A.A. 